\title{
Perbandingan Kinerja Keuangan BUSN Devisa Konvensional dan BUSN Non Devisa Konvensional
}

\author{
Ma'ulvi Marsela Devi \\ Universitas Hayam Wuruk Perbanas (d/h STIE Perbanas Surabaya) \\ Evi Sistiyarini \\ Universitas Hayam Wuruk Perbanas (d/h STIE Perbanas Surabaya) \\ *marseladevi3@gmail.com \\ *evi.sistiyarini@perbanas.ac.id
}

\begin{abstract}
Abstrak
Penelitian ini bertujuan untuk mengetahui perbedaan yang signifikan pada LDR, CR, NPL, APB, NIM, ROA, CAR dan DR antara Bank Umum Swasta Nasional Devisa Konvensional dan Bank Umum Swasta Nasional Non Devisa Konvensional pada periode triwulan satu tahun 2015 sampai dengan triwulan empat 2019. Sampel dalam penelitian ini adalah Bank Bumi Arta, Bank Maspion, Bank MNC Internasional, Bank Yudha, Bank Jasa Jakarta dan Bank Sahabat Sampoerna. Penelitian ini menggunakan data sekunder, teknik pengambilan sampel menggunakan Purposive Sampling dan teknik analisis data menggunakan independent simple $t$ test. Hasil dari penelitian ini menunjukkan bahwa terdapat perbedaan yang signifikan pada LDR, CR, NPL, APB, NIM, ROA, dan CAR dan terdapat perbedaan yang tidak signifikan pada DR.
\end{abstract}

Kata Kunci: LDR, CR, NPL, APB, NIM, ROA, CAR dan DR

\section{Pendahuluan}

Bank berperan penting sebagai faktor penggerak roda perekonomian suatu bangsa dan negara, terdapat dua jenis peran perbankan yaitu peran dalam negeri dan peran luar negeri. Peran dalam negeri, bank dapat memenuhi kebutuhan ekonomi seperti kegiatan administrasi keuangan, kegiatan penampungan uang, kegiatan penggunaan uang, kegiatan penukaran uang, kegiatan pengawasan uang, kegiatan perkreditan, dan kegiatan pengiriman uang. Peran luar negeri, bank memiliki peran untuk melakukan kegiatan yang meliputi hal-hal yang berkaitan dengan lalu lintas devisa, kegiatan hubungan perdagangan dan kegiatan hubungan moneter antar negara.

Sistem bank antara BUSN devisa konvensional dan BUSN non devisa konvensional terdapat perbedaan, yaitu BUSN devisa konvensional dapat melakukan transaksi valuta asing, sedangkan BUSN non devisa konvensional tidak bisa melakukan transaksi tersebut, adanya perbedaan dari kegiatan usaha bank non devisa konvensional dipastikan kalah dalam bersaing di dunia perbankan, oleh karena itu bank non devisa konvensional harus memiliki kinerja yang jauh lebih baik dan lebih unggul supaya memenangkan persaingan.

Penelitian ini bertujuan untuk melihat perbedaan kinerja keuangan antara bank umum swasta nasional devisa konvensional dan bank umum swasta nasional non devisa konvensional. Pengukuran kinerja yang digunakan adalah rasio LDR (Loan to Deposit Ratio), CR (Current Ratio), NPL (Non Performing Loan), APB (Aset Produktif Bermasalah), NIM 
(Net Interest Margin), ROA (Return On Assets), CAR (Capital Adequacy Ratio), dan DR (Debt Ratio). Objek dari penelitian ini adalah seluruh bank devisa dan bank non devisa yang tercatat di Bank Indonesia.

Tabel 1 menunjukkan bahwa terdapat beberapa indikator business problem dalam periode 2015 triwulan satu hingga 2019 triwulan empat. LDR BUSN Non Devisa Konvensional memiliki rata-rata LDR yang lebih tinggi dibandingkan dengan rata-rata LDR BUSN Devisa Konvensional. Jika LDR Bank semakin meningkat maka jumlah kredit yang disalurkan semakin meningkat sehingga pendapatan bunga juga semakin tinggi, laba dan ROA akan meningkat, akan tetapi rata-rata ROA BUSN Non Devisa justru semakin menurun. Rata-rata NPL dan APB BUSN Devisa Konvensional lebih tinggi dibandingkan BUSN Non Devisa Konvensional. Hal ini menunjukkan kualitas aset nya semakin rendah sehingga berdampak pada pendapatan bank yang semakin menurun, laba menurun dan ROA menurun, akan tetapi ROA BUSN Devisa semakin tinggi dibandingkan BUSN Non Devisa.

Tabel 1. Rasio Keuangan BUSN Devisa Konvensional dan BUSN Non Devisa Konvensional

\begin{tabular}{|l|l|l|l|l|l|l|l|l|l|l|l|l|}
\hline \multicolumn{9}{|c|}{ BUSN DEVISA KONVENSIONAL } & \multicolumn{4}{c|}{ BUSN NON DEVISA KONVENSIONAL } \\
$(\%)$
\end{tabular}

*Per Desember 2019

Sumber: Laporan Keuangan Masing-Masing Bank (2019)

Rata-rata ROA BUSN Devisa Konvensional lebih tinggi dibandingkan BUSN Non Devisa Konvensional. Hal ini meenunjukkan bahwa kemampuan menghasilkan laba BUSN Devisa Konvensional yang lebih tinggi. Jika kemampuan menghasilkan laba lebih tinggi, maka akan menambah modal bank dan rasio CAR semakin meningkat, akan tetapi tabel menunjukkan bahwa rasio CAR BUSN Devisa Konvensional justru semakin kecil dibandingkan dengan BUSN Non Devisa Konvensional.

Penelitian yang dilakukan oleh Putri, A., M \& Iradiyanti, A (2020) menemukan bahwa tidak terdapat perbedaan yang signifikan pada rasio CAR, NPL, ROA, BOPO Dan LDR Perbankan Syariah dengan Perbankan Konvensioal dan terdapat perbedaan yang signifikan pada variabel DER. Penelitian tersebut sejalan dengan penelitian Thessalonica dkk (2019) yang menemukan bahwa tidak terdapat yang signifikan ROA, ROE, NIM, CAR antara Bank Umum Milik Negara (BUMN) dan Bank Umum Swasta Nasional. Hal ini berbeda dengan penelitian Dwilita, H (2019) yang menemukan bahwa variabel CAR, NPF/NPL, ROA, BOPO, FDR/LDR memiliki perbedaaan yang signifikan pada Bank Umum Syariah dan Bank Umum Konvensional. 


\section{Landasan Teori dan Pengembangan Hipotesis}

\section{Pengertian Bank Umum}

Kasmir (2015:11) menyatakan "pengertian bank merupakan lembaga keuangan yang kegiatan utamanya adalah menghimpun dana dari masyarakat dan menyalukan kembali dana tersebut ke masyarakat serta memberikan jasa bank lainnya". Pengertian bank umum sesuai UU No. 10 Tahun 1998 pasal 1 ayat 2 adalah badan usaha yang menghimpun dana dari masyarakat dalam bentuk simpanan dan menyalurkannya dana kepada masyarakat dalam bentuk kredit dan atau bentuk lainnya serta memberikan pelayanan secara maksimal kepada nasabah dengan tujuan dalam rangka meningkatkan taraf hidup rakyat banyak. Dari segi status dibagi dalam dua macam, yaitu Bank Devisa yang merupakan bank yang dapat melakukan transaksi dengan menggunakan mata uang asing serta Bank Non Devisa yaitu bank yang tidak bisa melakukan transaksi dengan menggunakan mata uang asing.

\section{Pengertian Kinerja Keuangan Bank}

Kinerja keuangan adalah suatu analisis yang dilakukan untuk melihat sejauh mana suatu perusahaan telah melaksanakan dengan menggunakan aturan-aturan pelaksanaan keuangan secara baik dan benar. Kinerja perusahaan merupakan suatu gambaran tentang kondisi keuangan suatu perusahaan yang dianalisis dengan alat-alat analisis keuangan, sehingga dapat diketahui mengenai baik buruknya keadaan keuangan suatu perusahaan yang mencerminkan prestasi kerja dalam periode tertentu. Hal ini sangat penting sehingga sumber daya dapat digunakan secara optimal dalam menghadapi perubahan lingkungan (Irham Fahmi, I2017:142).

\section{Analisis Rasio Keuangan}

Rasio keuangan digunakan untuk mengukur kinerja keuangan perusahaan. Rasio keuangan merupakan kegiatan membandingkan angka-angka di dalam laporan keuangan dengan membagi satuangka dengan angka lainnya atau suatu cara yang digunakan untuk mengukur kondisi dan kinerja suatu perusahaan dengan laporan keuangan perusahaan tersebut (Kasmir, 2016:104).

\section{Rasio Likuiditas}

Rasio Likuiditas merupakan rasio yang menggambarkan kemampuan perusahaan dalam memenuhi kewajiban atau hutang jangka pendeknya (Kasmir, 2016:123). Dalam penelitian ini rasio likuiditas dihitung menggunakan LDR (Loan to Deposti Ratio) dan CR (Current Ratio). Loan to Deposit Ratio merupakan rasio untuk mengukur komposisi jumlah kredit yang diberikan dibandingkan dengan jumlah dana masyarakat dan modal yang digunakan (Kasmir: 2016, 160-170). Rumus yang digunakan untuk mengukur Loan to Deposit Ratio adalah sebagai berikut:

$$
\text { Loan to Deposit Ratio }=\frac{\text { Kredityang Diberikan }}{\text { Dana Pihak Ketiga }} \times 100 \%
$$

Penelitian yang dilakukan oleh Dwilita, H (2019) menemukan bahwa terdapat perbedaan yang signifikan pada LDR Bank Umum Syariah dan Bank Umum Konvensional. Hasil lain dikemukakan oleh Dewi, I.L \& Triaryati, N (2017) bahwa terdapat perbedaan LDR yang tidak signifikan antara BUMN dan Bank Asing.

H1: Terdapat perbedaan yang signifikan pada rasio LDR (Loan to Deposit Ratio) antara Bank Umum Swasta Nasional Devisa dan Bank Umum Swasta Nasional Non Devisa Konvensional. 
Erari, A (2014) menjelaskan bahwa Current Ratio kemampuan perusahaan dalam memenuhi kebutuhan operasionalnya. Semakin tinggi CR maka semakin baik kondisi likuiditas di perusahaan. Rumus yang digunakan untuk mengukur Current Ratio adalah sebagai berikut:

$$
\text { Current Ratio }=\frac{\text { Aktiva Lancar }}{\text { Hutang Lancar }} \times 100 \%
$$

H2: Terdapat perbedaan yang signifikan pada rasio CR (Current Ratio) antara Bank Umum Swasta Nasional Devisa dan Bank Umum Swasta Nasional Non Devisa Konvensional.

\section{Rasio Kualitas Aset}

Kualitas aset merupakan kemampuan bank dalam mengelola aktiva produktif yang merupakan sumber pendapaan bank yang digunakan untuk biaya operasional. Dalam penelitian ini rasio kualitas aset yang dihitung menggunakan NPL (Non Performing Loan) dan APB (Aktiva Produktif Bermasalah). NPL merupakan rasio yang digunakan untuk mengukur kemampuan bank dalam mengelola kredit dan rasio ini digunakan untuk membandingkan kredit lancar, kredit diragukan, kredit macet dan total kredit yang diberikan (Rivai, V: 2013, 473-474). Rasio ini dapat memperlihatkan kualitas portofolio kredit suatu bank (Sorongan, F., 2020). Penelitian yang dilakukan oleh Dwilita, H (2019) menemukan bahwa terdapat perbedaan yang signifikan antara NPL Bank Umum Syariah dan Bank Umum Konvensional. Penelitian tersebut juga mendukung penelitian Firdaus, M.E.A \& Worokinasih, S (2018) yang membuktikan bahwa terdapat perbedaan NPL yang signifikan pada BUMN dan Bank Asing. Hasil berbeda dilakukan oleh Thesalonica, dkk (2019) Derek, Z.A (2017) menyatakan bahwa tidak terdapat perbedaan yang signifikan. Rumus yang digunakan untuk mengukur Non performing Loan adalah sebagai berikut:

$$
\text { Non Performing Loan }=\frac{\text { Kredit Bermasalah }}{\text { Total Kredit }} \times 100 \%
$$

H3: Terdapat perbedaan yang signifikan pada rasio NPL (Non Perorming Loan) antara Bank Umum Swasta Nasional Devisa dan Bank Umum Swasta Nasional Non Devisa Konvensional.

APB merupakan rasio aktiva produktif bermasalah yang diukur menggunakan total aktiva produktif. Aktiva produktif bermasalah yang semakin besar mengindikasikan bahwa telah terjadi penurunan pendapatan bank. Rumus untuk menghitung Aktiva Produktif Bermasalah adalah sebagai berikut:

$$
\text { Aktiva Produktif Bermasalah }=\frac{\text { Aktiva Produktif Bermasalah }}{\text { Total Aktiva Produktif }} x 100 \%
$$

H4: Terdapat perbedaan yang signifikan pada rasio APB (Aktiva Produktif Bermasalah) antara Bank Umum Swasta Nasional Devisa dan Bank Umum Swasta Nasional Non Devisa Konvensional.

\section{Rasio Rentabilitas}

Kasmir (2016:196) menyebutkan bahwa rasio rentabilitas sering disebut sebagai profitabilitas usaha. Rasio ini digunakan untuk mengukur tingkat efesiensi usaha dan profit yang dicapai oleh bank. Dalam Penelitian ini rasio rentabilitas yang dihitung menggunakan NIM (Net Interest Margin) dan ROA (Return On Assets). Net Interest Margin merupakan rasio yang menunjukkan kemampuan earning assets dalam menghasilkan pendapatan bunga 
bersih. Dewi, I.L \& Triaryati, N (2017) menyebutkan bahwa NIM yang tinggi tidak selalu baik karena dapat menyebabkan bank menurunkan margin bersih untuk peningkatan efisiensi bank. Hasil penelitian Dewi, I.L \& Triaryati, N (2017) menemukan bahwa terdapat perbedaan NIM yang signifikan antara BUMN dan Bank Asing. Hasil yang berbeda dilakukan oleh Derek, Z.A (2017), Dwilita, H (2019), Thesalonica dkk (2019) yang menyatakan bahwa tidak terdapat perbedaan yang signifikan. Rumus yang digunakan untuk mengukur Net Interest Margin adalah sebagai berikut (Kasmir: 2016, 327-328).

$$
\text { Net Interest Margin }=\frac{\text { Pendapatan Bunga Bersih }}{\text { Altiva Produktif }} \times 100 \%
$$

H5: Terdapat perbedaan yang signifikan pada rasio NIM (Net Interest Margin) antara Bank Umum Swasta Nasional Devisa dan Bank Umum Swasta Nasional Non Devisa Konvensional.

Return On Assets (ROA) yaitu rasio yang digunakan untuk kemampuan manajemen bank dalam memperoleh keuntungan secara keseluruhan, semakin besar ROA maka semakin besar pula tingkat laba yang akan dicapai bank tersebut dan semakin baik pula posisi bank dari segi penggunaan aset. Penelitian yang dilakukan oleh Dwilita, H (2019) menemukan bahwa terdapat perbedaan yang signifikan pada ROA Bank Umum Syariah dan Bank Umum Konvensional. Hasil lain dikemukakan oleh Dewi, I.L \& Triaryati, N (2017) bahwa terdapat perbedaan ROA yang tidak signifikan antara BUMN dan Bank Asing. Rumus yang digunakan untuk mengukur Return On Assets adalah sebagai berikut:

$$
\text { ROA }=\frac{\text { Laba Sebelum Pajak }}{\text { Rata-Rata Total Aset }} \chi 100 \%
$$

H6: Terdapat perbedaan yang signifikan pada rasio ROA (Return On Asset) antara Bank Umum Swasta Nasional Devisa dan Bank Umum Swasta Nasional Non Devisa Konvensional.

\section{Rasio Permodalan}

Kasmir (2016:325) menyebutkan bahwa pengertian dari rasio permodalan yaitu rasio yang digunakan untuk mengukur permodalan dan cadangan penghapusan dalam menanggung perkreditan, terutama risiko yang terjadi karena bunga gagal tagih. Rasio permodalan dapat dihitung menggunakan CAR (Capital Adequacy Margin) dan DR (Debt Rasio) (Kasmir: 2016, 325-350)

Capital Adequacy Ratio (CAR) merupakan rasio yang digunakan untuk membiayai aktivitas kegiatannya dengan modal sendiri serta mengukur kecukupan modal yang dimiliki oleh bank tersebut untuk menunjang aktiva yang menghasilkan risiko, seperti pemberian pinjaman kredit. Penelitian yang dilakukan oleh Dwilita, H (2019) menemukan bahwa terdapat perbedaan yang signifikan pada CAR Bank Umum Syariah dan Bank Umum Konvensional. Hasil penelitian tersebut mendukung penelitian Dewi, I.L \& Triaryati, N (2017) menemukan bahwa terdapat perbedaan CAR yang signifikan antara BUMN dan Bank Asing. Rumus yang digunakan untuk mengukur Capital Adequacy Ratio adalah sebagai berikut:

$$
C A R=\frac{\text { Modal Sendiri }}{\text { ATMR }} \times 100 \%
$$


H7: Terdapat perbedaan yang signifikan pada rasio CAR (Capital Adequacy Ratio) antara Bank Umum Swasta Nasional Devisa dan Bank Umum Swasta Nasional Non Devisa Konvensional.

Debt Ratio merupakan rasio utang yang digunakan untuk mengukur pebandingan antara total utang dengan total aktiva, dengan kata lain, seberapa besar aktiva perusahaan dibiayai oleh hutang atau seberapa besar hutang perusahaan berpengaruh terhadap pengelolaan aktiva. Rumus yang digunakan untuk mengukur Debt Ratio adalah sebagai berikut

$$
\mathrm{DR}=\frac{\text { Total hutang }}{\text { Total aset }} \times 100 \%
$$

H8: Terdapat perbedaan yang signinfikan pada rasio DR (Debt Ratio) antara Bank Umum Swasta Nasional Devisa dan Bank Umum Swasta Nasional Non Devisa Konvensional

\section{Metode Penelitian}

\section{Jenis Penelitian}

Berdasarkan tujuannya, penelitian ini termasuk jenis penelitian komparatif karena bersifat membandingkan keadaan satu variabel atau lebih pada dua atau lebih sampel yang berbeda dengan waktu yang berbeda (Sugiyono 2017:54).

\section{Identifikasi Variabel}

Berdasarkan permasalahan, tujuan dan hipotesis dalam penelitian ini maka variable yang digunakan adalah:

1. Likuiditas
a. LDR (Loan to Deposit Ratio)
b. CR (Current Ratio)

2. Kualitas Aset
a. NPL (Non Performing Loan)
b. APB (Aktiva Produktif Bermasalah)

3. Rentabilitas
a. NIM (Net Interest Margin)
b. ROA (Return On Assets)

4. Permodalan

a. CAR (Capital Adequacy Ratio)

\section{Data dan Metode Pengumpulan Data}

Penelitian ini menggunakan data sekunder yaitu data yang diperoleh dari laporan keuangan publikasi Otoritas Jasa Keuangan (OJK) pada periode triwulan satu tahun 2015 sampai dengan tahun triwulan empat tahun 2019. Metode yang digunakan dalam penelitian ini yaitu metode dokumentasi atau pengumpulan data yang diperoleh dari laporan keuangan BUSN Devisa Konvensional dan BUSN Non Devisa Konvensional serta website masingmasing bank.

\section{Teknik Analisis Data}

Metode atau Teknik analisis yang digunakan dalam penelitian ini adalah: 


\section{Analisis deskriptif}

Sugiyono (2017:35) menyatakan penelitian deskriptif adalah metode penelitian yang dilakukan untuk mengetahui keberadaan variabel mandiri, baik hanya pada satu variabel atau lebih (variabel yang berdiri sendiri atau variabel bebas) tanpa membuat perbandingan variabel itu sendiri dan mencari hubungan dengan variabel lain. Analisis deskriptif digunakan untuk memberikan gambaran tentang kinerja keuangan yang terdiri dari LDR, CR, NPL, APB, NIM, ROA, CAR dan DR pada BUSN Devisa Konvensional dan BUSN Non Devisa Konvensional.

2. Analisis Inferensial

Analisis ini digunakan untuk mengetahui perbedaan yang signifikan pada LDR, CR, NPL, APB, NIM, ROA, CAR dan DR antara BUSN devisa konvensional dengan BUSN non devisa konvensional. Metode yang digunakan adalah uji beda dua rata-rata sampel bebas (independent sample t test).

\section{Pembahasan}

\section{Analisis Deskriptif}

Rata-rata LDR pada BUSN Devisa Konvensional lebih besar dibandingkan BUSN Non Devisa Konvensional. Rata-rata LDR BUSN Devisa Konvensional sebesar 90.85 persen sedangkan rata-rata LDR pada BUSN Non Devisa konvensional sebesar 85.85 persen. Hal ini menunjukkan bahwa BUSN Devisa Konvensional memiliki likuiditas yang lebih baik karena lebih mampu memenuhi kewajiban kepada pihak ketiga dengan mengandalkan kredit sebagai sumber likuiditasnya.

Rata-rata CR pada BUSN Devisa Konvensional lebih besar dibandingkan BUSN Non Devisa Konvensional. Rata-rata CR BUSN Devisa Konvensional sebesar 29.60 persen sedangkan rata-rata CR pada BUSN Non Devisa Konvensional sebesar 24.71 persen, jika dilihat nilai rata-rata kedua bank tersebut maka nilai yang paling tinggi yaitu BUSN Devisa Konvensional karena BUSN Devisa Konvensional lebih mampu untuk memenuhi kewajiban jangka pendek, sehingga dapat disimpulkan bahwa BUSN Devisa Konvensional memiliki likuiditas yang lebih baik.

Rata-rata NPL pada BUSN Devisa Konvensional lebih kecil dibandingkan BUSN Non Devisa Konvensional. Rata-rata NPL BUSN Devisa Konvensional sebesar 2.85 persen sedangkan rata-rata NPL pada BUSN Non Devisa Konvensional sebesar 4.27 persen. Hal ini menunjukkan bahwa BUSN Devisa Konvensional memiliki kredit bermasalah yang lebih rendah dibandingkan dengan BUSN Non Devisa Konvensional, sehingga kualitas aset BUSN Devisa Konvensional lebih baik.

Rata-rata APB pada BUSN Devisa Konvensional lebih kecil dibandingkan BUSN Non Devisa Konvensional. Rata-rata APB BUSN Devisa Konvensional sebesar 1.94 persen sedangkan rata-rata APB pada BUSN Non Devisa Konvensional sebesar 3.15 persen, Hal ini menunjukkan bahwa BUSN Devisa Konvensional memiliki aset produktif bermasalah yang lebih rendah dan kualitas aset yang lebih baik dibandingkan dengan BUSN Non Devisa Konvensional.

Rata-rata NIM pada BUSN Devisa Konvensional lebih kecil dibandingkan BUSN Non Devisa Kovensional. Rata-rata NIM BUSN Devisa Konvensional sebesar 2.51 persen. Hal ini menunjukkan bahwa BUSN Non Devisa Konvensional lebih mampu mengelola produktifitasnya untuk menghasilkan pendapatan bunga.

Rata-rata ROA pada BUSN Devisa Konvensional lebih kecil dibandingkan BUSN Non Devisa Konvensional. Rata-rata ROA BUSN Devisa Konvensional sebesar 0.46 persen, 
sedangkan rata-rata ROA pada BUSN Non Devisa Konvensional sebesar 0.93 persen. Hal ini menunjukkan bahwa BUSN Devisa kemampuan dalam menghasilkan laba yang lebih rendah dari BUSN Non Devisa, sehingga dapat disimpulkan bahwa BUSN Non Devisa Konvensional memiliki profitabilitas yang lebih baik.

Rata-rata CAR pada BUSN Devisa Konvensional lebih kecil dibandingkan BUSN Non Devisa Konvensional. Rata-rata CAR BUSN Devisa Konvensional sebesar 20.20 persen, sedangkan rata-rata CAR pada BUSN Non Devisa Konvensional sebesar 23.76 persen. Hal ini menunjukkan bahwa BUSN Non Devisa Konvensional memiliki struktur permodalan yang lebih baik dan lebih kuat dibandingkan dengan BUSN Devisa sehingga lebih mampu dalam menghadapi risiko perbankan.

Rata-rata DR pada BUSN Devisa Konvensional lebih besar dibandingkan BUSN Non Devisa Konvensional. Rata-rata DR BUSN Devisa Konvensional sebesar 83.70 persen, sedangkan rata-rata DR pada BUSN Non Devisa Konvensionla sebesar 83.01 persen. Hal ini menunjukkan bahwa BUSN Non Devisa Konvensional lebih baik dalam menggunakan sumber pembiayaan dengan hutang.

\section{Variabel LDR}

Berdasarkan uji statistik pada rasio LDR diperoleh $-\mathrm{t}_{\text {hitung }}<-\mathrm{t}_{\text {tabel }}=-4.201<-1.980$. Hasil tersebut dapat dijelaskan bahwa terdapat perbedaan yang signifikan antara BUSN Devisa Konvensional dan BUSN Non Devisa Konvensional. LDR pada BUSN Devisa Konvensional sebesar 85.85 persen dan BUSN Non Devisa Konvensional tercatat 90.85 persen. Hasil menunjukkan bahwa BUSN Devisa Konvensional dan BUSN Non Devisa Konvensional memenuhi besaran dan parameter yang ditentukan oleh Bank Indonesia yaitu sebesar 78 persen sampai dengan 92 persen. Semakin tinggi nilai LDR bank maka semakin tinggi kemampuan bank dalam menyalurkan kredit dari sumber dana pihak ketiga. Nilai kedua bank menunjukan bahwa BUSN Non Devisa Konvensional yang lebih baik karena memiliki rata-rata yang mendekati batas atas LDR, serta menunjukkan bahwa BUSN Non Devisa Konvensional lebih baik dalam memenuhi kewajiban terhadap dana pihak ketiga dengan mengandalkan kredit yang diberikan. Penelitian ini sejalan dengan penelitian yang dilakukan oleh Dwilita, H (2019) menemukan bahwa terdapat perbedaan yang signifikan pada LDR Bank Umum Syariah dan Bank Umum Konvensional. Penelitian ini tidak sejalan dengan penelitian Dewi, I.L \& Triaryati, N (2017).

\section{Variabel CR}

Berdasarkan uji statistik pada rasio CR diperoleh $t_{\text {hitung }}>t_{\text {tabel }}=3.380>1.980$. Hasil tersebut dapat dijelaskan bahwa terdapat perbedaan yang signifikan antara BUSN Devisa Konvensional dan BUSN Non Devisa Konvensional. CR pada BUSN Devisa Konvensional tercatat 29.60 persen dan BUSN Non Devisa Konvensional tercatat 24.71 persen. Nilai kedua bank menunjukkan bahwa BUSN Devisa Konvensional yang lebih baik karena memiliki ratarata yang lebih besar dan hal tersebut menunjukkan bahwa BUSN Devisa Konvensional memiliki kemampuan yang lebih baik untuk membayar kewajiban jangka pendeknya dibandingkan dengan BUSN Non Devisa Konvensional, dan hal ini juga dibuktikan dengan pengujian hipotesis yang telah dilakukan dan menyatakan bahwa terdapat perbedaan yang signifikan pada CR antara BUSN Devisa Konvensional dan BUSN Non Devisa Konvensional. Hasil sesuai dengan penelitian yang dilakukan oleh Derek, Z.E, dkk (2017) menyatakan bahwa terdapat perbedaan signifikan dan tidak sejalan dengan penelitian yang dilakukan oleh Dwilita, H (2019), Thesalonica dkk (2019). 


\section{Variabel NPL}

Berdasarkan uji statistik pada rasio NPL diperoleh $-\mathrm{t}_{\text {hitung }}<-\mathrm{t}_{\text {tabel }}=-2.208<-1.980$. Hasil tersebut dapat dijelaskan bahwa terdapat perbedaan yang signifikan antara BUSN Devisa Konvensional dan BUSN Non Devisa Konvensional. NPL pada BUSN Devisa Konvensional tercatat 2.85 persen dan BUSN Non Devisa Konvensional tercatat 4.27 persen. Hasil menunjukkan bahwa BUSN Devisa Konvensional dan BUSN Non Devisa Konvensional mampu mengelola kredit bermasalah dan memenuhi syarat Bank Indonesia yang menyatakan bahwa ketentuan NPL maksimal 5 persen. Nilai kedua bank menunjukkan bahwa BUSN Devisa Konvensional yang lebih baik karena memiliki jumlah kredit bermasalah lebih sedikit dibandingkan dengan BUSN Non Devisa Konvensional. Hal ini dibuktikan dengan pengujian hipotesis yang telah dilakukan dan menyatakan bahwa terdapat perbedaan yang signifikan pada NPL antara BUSN Devisa Konvensional dan BUSN Non Devisa Konvensional. Hasil penelitian ini mendukung penelitian yang dilakukan oleh Dwilita, H (2019), Firdaus, M.E.A \& Worokinasih, S (2018) menemukan bahwa terdapat perbedaan rasio NPL yang signifikan. Penelitian ini tidak mendukung penelitian Thesalonica, dkk (2019) Derek, Z.A (2017) menyatakan bahwa tidak terdapat perbedaan yang signifikan.

\section{Variabel APB}

Berdasarkan uji statistik pada rasio APB diperoleh $-\mathrm{t}_{\text {hitung }}<-\mathrm{t}_{\text {tabel }}=-2.292<-1.980$. Hasil tersebut dapat dijelaskan bahwa terdapat perbedaan yang signifikan antara BUSN Devisa Konvensional dan BUSN Non Devisa Konvensional. APB pada BUSN Devisa Konvensional tercatat 1.94 persen dan BUSN Non Devisa Konvensional tercatat 3.15 persen. Nilai kedua bank menunjukkan bahwa BUSN Devisa Konvensional yang lebih baik karena memiliki rata-rata yang lebih kecil, yang menunjukkan bahwa tingkat kolektibilitasnya rendah dan hal ini berkaitan dengan LDR yang menyatakan bahwa volume kredit yang disalurkan oleh BUSN Devisa Konvensional lebih sedikit sehingga tingkat kolektibilitasnya juga rendah. Hasil menunjukkan bahwa BUSN Devisa Konvensional memiliki kemampuan dalam mengelola aktiva produktifnya sehingga kemungkinan potensi gagal bayar lebih kecil dibandingkan dengan BUSN Non Devisa Konvensional. Hasil penelitian tidak sesuai dengan penelitian yang dilakukan oleh Derek, Z.A (2017), Dwilita, H (2019), Thesalonica dkk (2019), yang menyatakan bahwa tidak terdapat perbedaan yang signifikan.

\section{Variabel NIM}

Berdasarkan uji statistik pada rasio NIM diperoleh $-\mathrm{t}_{\text {hitung }}<-\mathrm{t}_{\text {tabel }}=-2.199<-1.980$. Hasil tersebut dapat dijelaskan bahwa terdapat perbedaan yang signifikan antara BUSN Devisa Konvensional dan BUSN Non Devisa Konvensional. Hasil penelitian menunjukkan bahwa BUSN Devisa Konvensional dan BUSN Non Devisa Konvensional belum memenuhi ketentuan Bank Indonesia yang menyatakan bahwa nilai NIM minimal 6 persen, jika dilihat dari nilai kedua bank menunjukkan bahwa BUSN Non Devisa Konvensional yang lebih baik karena memiliki nilai rata-rata yang lebih besar dan lebih baik dalam mengelola aktiva produktifnya untuk menghasilkan pendapatan bunga bersih dibandingkan dengan BUSN Devisa Konvensional. Hal ini dibuktikan dengan pengujian hipotesis yang telah dilakukan dan menyatakan bahwa terdapat perbedaan yang signifikan pada NIM antara BUSN Devisa Konvensional dan BUSN Non Devisa Konvensional. Hasil penelitian ini sejalan dengan penelitian Dewi, I.L \& Triaryati, N (2017) menemukan bahwa terdapat perbedaan NIM yang signifikan antara BUMN dan Bank Asing. Penelitian ini bertentangan dengan Derek, Z.A (2017), Dwilita, H (2019), Thesalonica dkk (2019) yang menyatakan bahwa tidak terdapat perbedaan yang signifikan. 


\section{Variabel ROA}

Berdasarkan uji statistik pada rasio ROA diperoleh $-\mathrm{t}_{\text {hitung }}<-\mathrm{t}_{\text {tabel }}=-2.354<-1.980$. Hasil tersebut dapat dijelaskan bahwa terdapat perbedaan yang signifikan antara BUSN Devisa Konvensional dan BUSN Non Devisa Konvensional. ROA pada BUSN Devisa Konvensional sebesar 0.46 persen dan BUSN Non Devisa Konvensional sebesar 0.93 persen. Hasil menunjukkan bahwa BUSN Devisa Konvensional dan BUSN Non Devisa Konvensional sudah memenuhi ketentuan Bank Indonesia bahwa nilai ROA minimal 0 persen dan maksimal lebih dari 1.5 persen. Nilai dari kedua bank tersebut menunjukkan bahwa BUSN Non Devisa Konvensional lebih baik dalam penggunaan aset untuk memperoleh laba dibandingkan BUSN Devisa Konvensional, hal ini dibuktikan dengan pengujian hipotesis yang telah dilakukan dan menyatakan bahwa terdapat perbedaan yang signifikan pada ROA antara BUSN Devisa Konvensional dan BUSN Non Devisa Konvensional. Penelitian ini mendukung penelitian yang dilakukan oleh Dwilita, H (2019) menemukan bahwa terdapat perbedaan yang signifikan pada ROA Bank Umum Syariah dan Bank Umum Konvensional. Penelitian ini tidak mendukung penelitian Dewi, I.L \& Triaryati, N (2017) bahwa terdapat perbedaan ROA yang tidak signifikan antara BUMN dan Bank Asing.

\section{Variabel CAR}

Berdasarkan uji statistik pada rasio CAR diperoleh $-\mathrm{t}_{\text {hitung }}<-\mathrm{t}_{\text {tabel }}=-3.448<-1.980$. Hasil tersebut dapat dijelaskan bahwa terdapat perbedaan yang signifikan antara BUSN Devisa Konvensional dan BUSN Non Devisa Konvensional. CAR pada BUSN Devisa Konvensional tercatat 20.20 persen dan BUSN Non Devisa Konvensional tercatat 27.36 persen. Hasil menunjukkan bahwa BUSN Non Devisa Konvensional dan BUSN Non Devisa Konvensional sudah memenuhi ketentuan Bank Indonesia bahwa nilai CAR minimal 8 persen, jika dilihat dari nilai kedua bank menunjukkan bahwa BUSN Non Devisa Konvensional yang lebih baik karena semakin tinggi CAR, maka semakin mampu menanggung risiko dari setiap kredit. Hal ini dibuktikan dengan pengujian hipotesis yang telah dilakukan dan menyatakan bahwa terdapat perbedaan yang signifikan pada CAR antara BUSN Devisa Konvensional dan BUSN Non Devisa Konvensional. Hasil penelitian ini mendukung penelitian Dewi, I.L \& Triaryati, N (2017) menemukan bahwa terdapat perbedaan CAR yang signifikan antara BUMN dan Bank Asing.

\section{Variabel DR}

Berdasarkan uji statistik pada rasio DR diperoleh $t_{\text {hitung }}<t_{\text {tabel }}=1.074<1.980$. Hasil tersebut dapat dijelaskan bahwa tidak terdapat perbedaan yang signifikan antara BUSN Devisa Konvensional dan BUSN Non Devisa Konvensional. DR pada BUSN Devisa Konvensional tercatat 83.70 persen dan BUSN Non Devisa Konvensional tercatat 83.01 persen. Nilai kedua bank menunjukkan bahwa BUSN Devisa Non Konvensional yang lebih baik karena memiliki rata-rata yang lebih kecil dan hal tersebut menunjukkan bahwa lebih baik dalam menggunakan sumber pembiayaan dengan hutang dibandingkan dengan BUSN Devisa Konvensional, hal ini dibuktikan dengan pengujian hipotesis yang telah dilakukan dan menyatakan bahwa terdapat perbedaan yang tidak signifikan pada DR antara BUSN Devisa Konvensional dan BUSN Non Devisa Konvensional. Hasil penelitian tidak sesuai dengan penelitian yang dilakukan oleh Derek, Z.A (2017), Dwilita, H (2019), Thesalonica dkk (2019) yang menyatakan bahwa tidak terdapat perbedaan yang signifikan. 


\section{Kesimpulan}

Berdasarkan perhitungan dan analisis yang telah dilakukan, maka hasil dari penelitian ini yaitu terdapat perbedaan yang signifikan pada rasio LDR antara BUSN Devisa Konvensional dan BUSN Non Devisa Konvensional. Nilai rata-rata LDR BUSN Non Devisa Konvensional yang lebih tinggi menunjukkan kemampuan dalam menyalurkan kredit yang lebih baik daripada BUSN Devisa Konvensional. Terdapat perbedaan yang signifikan pada rasio CR antara BUSN Devisa Konvensional dan BUSN Non Devisa Konvensional. Nilai rata-rata CR pada BUSN Devisa Konvensional yang lebih tinggi menunjukkan kemampuan yang lebih baik untuk membayar kewajiban jangka pendeknya daripada BUSN Non Devisa Konvensional. Terdapat perbedaan yang signifikan pada rasio NPL antara BUSN Devisa Konvensional dan BUSN Non Devisa Konvensional. Nilai rata-rata NPL pada BUSN Devisa Konvensional yang lebih rendah menunjukkan adanya kemampuan yang lebih baik dalam mengelola kredit bermasalah dibandingkan BUSN Non Devisa Konvensional. Terdapat perbedaan yang signifikan pada rasio APB antara BUSN Devisa Konvensional dan BUSN Non Devisa Konvensional. Nilai rata-rata APB pada BUSN Devisa Konvensional lebih rendah menunjukkan kemampuan yang lebih baik dalam mengelola asset produktif bermasalah dibandingkan dengan BUSN Non Devisa Konvensional.

Terdapat perbedaan yang signifikan pada rasio NIM antara BUSN Devisa Konvensional dan BUSN Non Devisa Konvensional. Nilai rata-rata NIM BUSN Non Devisa Konvensional lebih besar menunjukkan adanya kemampuan yang lebih baik dalam mengelola aktiva produktifnya untuk menghasilkan pendapatan bunga bersih dibandingkan dengan BUSN Devisa Konvensional. Terdapat perbedaan yang signifikan pada rasio ROA antara BUSN Devisa Konvensional dan BUSN Non Devisa Konvensional. Nilai rata-rata ROA BUSN Non Devisa Konvensional lebih tinggi menunjukkan kemampuan menghasilkan laba yang lebih baik dari BUSN Devisa Konvensioal. Terdapat perbedaan yang signifikan pada rasio CAR antara BUSN Devisa Konvensional dan BUSN Non Devisa Konvensional. Nilai rata-rata CAR BUSN Non Devisa Konvensional lebih tinggi dibandingkan BUSN Devisa Konvensional. Hal ini menunjukkan bahwa BUSN Non Devisa Konvensional memiliki struktur permodalan yang lebih baik dan lebih kuat. Tidak terdapat perbedaan yang signifikan pada rasio DR antara BUSN Devisa Konvensional dan BUSN Non Devisa Konvensional. Nilai rata-rata DR pada BUSN Non Devisa Konvensional lebih kecil sehingga menunjukkan kemampuan yang lebih baik dalam menggunakan sumber pembiayaan dengan hutang dibandingkan dengan BUSN Devisa Konvensional. Hasil penelitian ini memberikan implikasi teoritis pada kinerja BUSN Devisa Konvensional dan Devisa Non Devisa Konvensional. Secara keseluruhan BUSN Devisa Konvensional memiliki kinerja likuiditas dan kualitas asset yang lebih baik, sedangkan BUSN Non Devisa Konvensional memiliki kinerja rentabilitas dan permodalan yang lebih dibandingkan BUSN Devisa Konvensional. Implikasi praktis dari penelitian ini adalah BUSN Devisa Konvensional dapat meningkatkan kinerja kinerja rentabilitas dan permodalan, sedangkan BUSN Non Devisa Konvensional dapat meningkatkan kinerja likuiditas dan kualitas asset.

\section{Daftar Pustaka}

Bank Bumi Arta. (2020). Profil Perusahaan. www.bankbba.co.id diakses 12 Mei 2020

Bank Jasa Jakarta. (2020). Profil Perusahaan. www.bjj.co.id diakses 12 Mei 2020

Bank Maspion. (2020). Profil Perusahaan. www.bankmaspion.co.id diakses 12 Mei 2020 
Bank MNC Internasional. (2020). Profil Perusahaan. www.mncbank.co.id diakses 12 Mei 2020

Bank Sahabat Sampoerna. (2020). Profil Perusahaan.www.banksampoerna.com diakses 12 Mei 2020

Bank Yudha Bhakti. (2020). Profil Perusahaan. www.yudhabhakti.co.id diakses 12 Mei 2020

Dewi, I.L \& Triaryati, N (2017). "Pengaruh Faktor Internal dan Eksternal Bank Terhadap Net Interest Margin di Indonesia". E-Journal Management Unud, 6(6), 3051-3079.

Erari, A (2014). “Analisis Pengaruh Current Ratio, Debt to Equity Ratio dan Return On Asset Terhadap Return Saham Pada Perusahaan Pertambangan di Bursa Efek Indonesia”. Jurnal Manajemen dan Bisnis, 5(2), 174-191.

Handrayani Dwilita. (2019). "Perbandingan Kinerja Perbankan Indonesia Studi Pada Bank Umum Konvensional Dan Bank Umum Syariah Yang Terdaftar Di Bursa Efek Indonesia". Jurnal Akuntasi Bisnis dan Publik, 10(1), 145-162.

Irham, Fahmi. (2015). Manajemen Kinerja, Teori dan Aplikasi. Bandung: Alfabeta.

Kasmir. (2015). Dasar-Dasar Perbankan Edisi Revisi. Jakarta: PT. Raja Grafindo Persada.

Kasmir. (2016). Analisis Laporan Keuanngan. Jakarta: PT. Raja Grafindo Persada.

Munawir. (2015). Analisis Laporan Keuangan. Yogyakarta: Liberty.

Otoritas Jasa Keuangan (OJK). (2019). Laporan Keuangan Publikasi. www.ojk.go.id diakses 12 Desember 2019.

Putri, A., M \& Iradiyanti, A. (2020). “Analisis Perbandingan Kinerja Keuangan Perbankan Syariah dengan Perbankan Konvensional 2015-2019”. Jurnal Mitra Manajemen, 4(8), 1103-1117.

Sorongan, F, A. (2020). "Pengaruh Rentabilitas, Non Performing Loan (NPL), Likuiditas dan Inflasi terhadap Rasio Kecukupan Modal (CAR) pada Bank Pembangunan Daerah Periode 2016-2019”. Jurnal Riset Manajemen Sains Indonesia, 11(2), 224-243.

Sugiyono. (2017). Metode Penelitian Kuantitatif Kualitatif dan R\&D. Bandung: Alfabeta.

Thessalonica S.F. Supit, Johny R.E. Tampi, \& Joanne Mangindaan. (2019). "Analisis Perbandingan Kinerja Keuangan Bank BUMN Dan Bank Swasta Nasional Yang Terdaftar Pada Bursa Efek Indonesia”. Jurnal EMBA, 7(8) ,3398-3407.

Veithzal, Rivai. Andria Permata Veithzal dan Arifandy Permata Veithzal. (2013). Credit Management Handbood. Jakarta: PT Grafindo Persada.

Zerah Elisa Derek, Parengkuan Tommy, \& Dedy Baramuli. 2017. “Analisis Perbandingan Kinerja Keuangan Pada Perusahaan Manufaktur Sub Sektor Industri Semen Yang Terdaftar Di Bursa Efek Indonesia”. Jurnal EMBA, 5(2) , 1738-1746. 